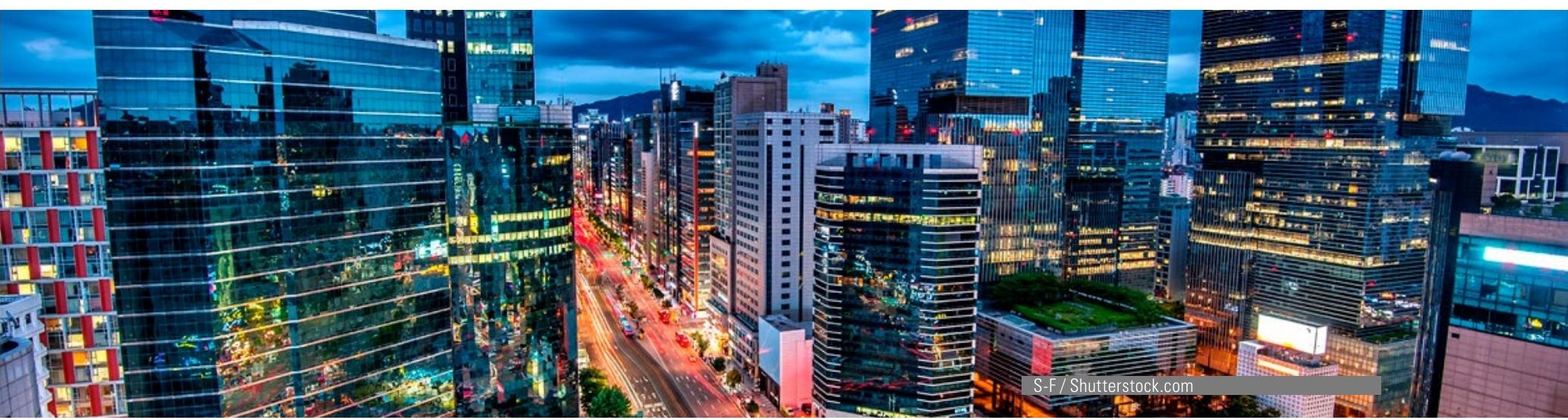

\title{
South Korea's lift-off to development: The role of Human Capital and Productivity in economic growth, 1960-1979
}

\section{El despegue de Corea del Sur hacia el desarrollo: El papel del capital humano y la productividad en el crecimiento económico, 1960-1979}

Francisco Javier Quiero Aguirre Ph. D (c) in Applied Economics Capital University of Economics and Business, Beijing francisco.quiero@gmail.com https://orcid.org/0000-0002-3897-1916

Recibido: 7 de febrero Aprobado: 9 de noviembre Publicado: 17 de diciembre

\section{Abstract}

South Korea is a case of impressive economic growth: a previously underdeveloped country that, after the 1960s, embarked on a process to achieve development before other underdeveloped countries. South Korea is also a case where innovation processes move from imitation to self-creation thanks to a quick updating or "catching up" process.

South Korea's journey from underdevelopment to development has sparked a rich and well-founded debate within economic theory. These debates weigh the roles of productive factors (Physical, Human, Social, and Financial Capital, Labor, resources, environment), economic agents (State, Firms, Banks), and international trade factors (FDI, Imports, Exports) on its growth process.

The central argument of this article establishes that Capital is the central variable that explains the successful outcome of the Korean growth miracle. However, Capital composition is even more important. The impact of Human Capital on the growth process evinces a synergy with Knowledge development. We modify the Solow model using Human, Physical Capital, and Total Factor Productivity as independent variables in a Multivariable Regression Model for the period between 1960 and 1979 on Output per worker. We conclude that Human Capital and Productivity are just as important as Physical Capital for explaining growth per worker in South Korea due their synergistic properties. The study is restricted to the years prior to Park Chung-Hee's rise to power and ends with his assassination. 


\section{Keywords}

South Korea, Economic growth, Human capital, Solow Model, Productivity

\section{Resumen}

Corea del Sur es un caso de impresionante crecimiento económico: un país previamente subdesarrollado que, después de la década de 1960, se embarcó en un proceso para lograr el desarrollo antes que otros países subdesarrollados. Corea del Sur también es un caso en el que los procesos de innovación pasan de la imitación a la auto-creación gracias a la capacidad de actualización rápida que los "mantiene al día".

El viaje de Corea del Sur del subdesarrollo al desarrollo ha provocado un debate rico y bien fundado dentro de la teoría económica. Estos debates ponderan los roles de los factores productivos: trabajo, recursos, medio ambiente, al igual que del capital físico, humano, social y financiero; como de los agentes económicos (Estado, Empresas, Bancos) y de los factores del comercio internacional (IED, Importaciones, Exportaciones) en su proceso de crecimiento.

El argumento central de este artículo establece que el capital es la variable central que explica el resultado exitoso del milagro del crecimiento coreano. Sin embargo, conocer de qué se compone el capital es aún más importante. El impacto del capital humano en el proceso de crecimiento evidencia una sinergia con el desarrollo del conocimiento. Modificamos el modelo de Solow utilizando el capital humano, el capital físico y la productividad total de los factores como variables independientes en un modelo de regresión multivariable para el período entre 1960 y 1979 sobre la producción por trabajador. Concluimos que el capital humano y la productividad son tan importantes como el capital físico para explicar el crecimiento por trabajador en Corea del Sur debido a sus propiedades sinérgicas. El estudio se limita a los años anteriores del ascenso al poder de Park Chung-Hee y termina con su asesinato.

\section{Palabras clave}

Corea del Sur, crecimiento económico, capital humano, modelo de Solow, productividad

\section{Introduction}

There is a consensus that South Korea intensified its Physical Capital (PC, from now on) accumulation between 1960 and 1979, but there is a lack of evidence on the role of Human Capital ( $\mathrm{HC}$, from now on) development during this period and even less on the synergy between Total Factor Productivity (TFP, from now on) and HC and its impact on Output.

¿What was the role played by Human and Physical Capital as they relate to Output per worker in South Korea between 1960 and 1979? The hypothesis of this article is to prove that the leap in South Korean development was made possible by the role of $\mathrm{HC}$ in Capital accumulation, enabling the correct development of the industrialization process via a combination of $\mathrm{HC}$ and Knowledge'. In consequence, we need to add the impact of education on Output per worker. As we know, empirical analysis is more complex than just creating a model with the idea of keeping all thing constant with exception of our variable of interest. An exogenous explanation is a necessary condition but is insufficient to explain this lift-off to development. By adding education to our model, we can keep the benefits of an exogenous model analysis while including endogenous elements of interest.

\footnotetext{
1 In this article we use Total Factor Productivity (TFP) as synonymous with Knowledge.
} 
The first part of this work will compare the different hypotheses on the South Korean case from a neoliberal, institutional, environmental, and heterodox approach. The second section will analyze the period between 1960 and 1979 using a historical-qualitative approach. These two sections summarize the state of the art regarding South Korea's economic growth and the institutional reforms required to achieve it. These two sections conclude that there is an absence of theory and empirical analysis focused on the role played by $\mathrm{HC}$ and Knowledge in Output per worker. In the third section, we will define the model and its supporting econometrics. Finally, in the Conclusion, we will analyze the results and evaluate the roles of PC, HC and TFP in Output per worker.

The time period under observation was selected for two main reasons: First, we used the World Bank Database, which defines Real Gross Domestic Product (GDP) and Capital Gross Formation (CGF) indexes per year for South Korea from 1960. Second, we needed to eliminate certain economic disturbances from the time series, to avoid data bias issues. There were economic crises in 1953 and 1980 that were not linked to local performance but to international factors. As our model uses a closed economy assumption, inclusion of these years will overestimate the regression model. Finally, we include complementary data from the Penn World Table 10 Database related to the Depreciation Value of Capital, Total Number of Workers and Human Capital Index for South Korea.

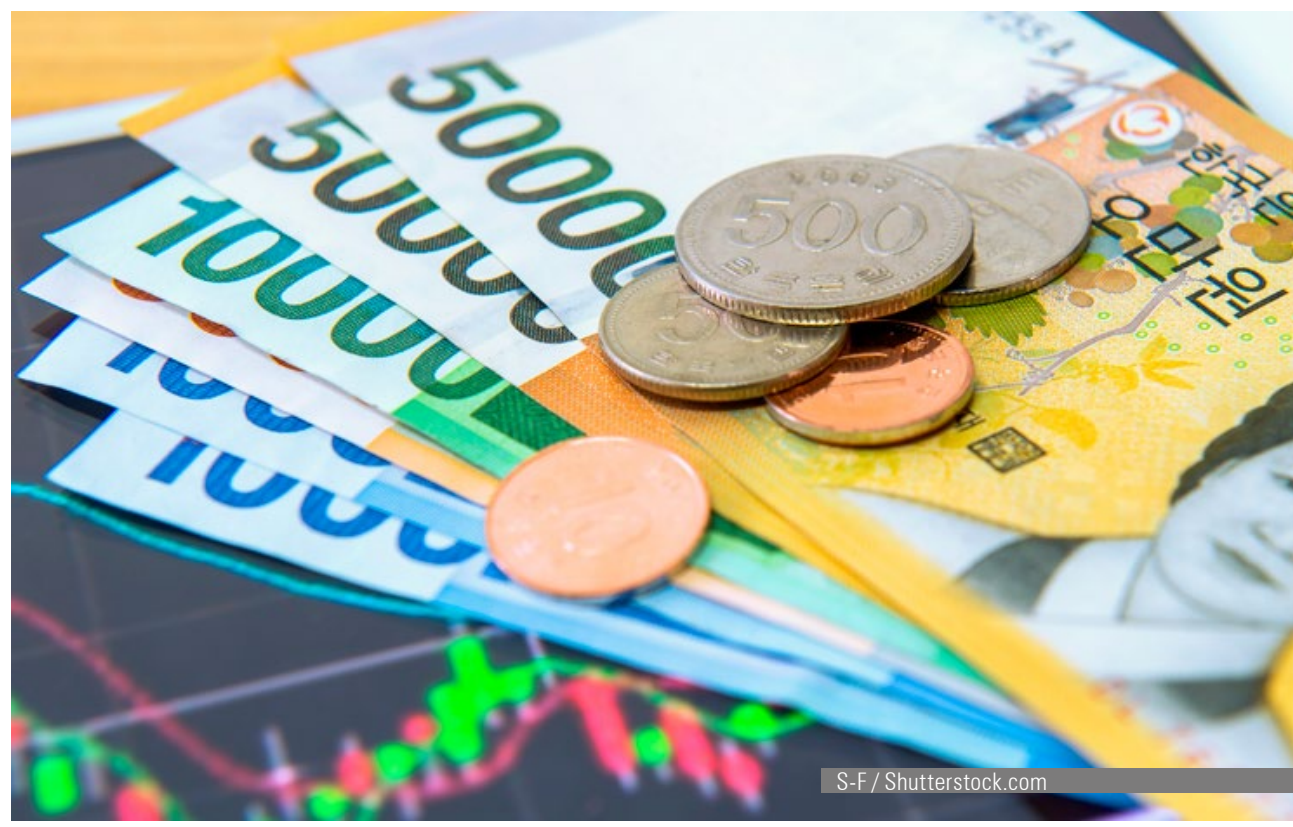

1. SOUTH KOREA'S DEVELOPMENT HYPOTHESIS

There is an abundance of economic theory literature using a variety of approaches. The Asian miracle is a subject that has been seriously assumed as a case study where the veracity of different theories is disputed.

Neoliberals view the Korean case as an example of free trade and clear property rights. Developmentalists view the Korean case as an example of how the State is indispensable for growth. Heterodox approaches combine the relevance of the State with the market, seeking to explain the transcendental factor that triggers growth. We will summarize the different hypotheses that seek to explain Korean development and how they suffer from analyzing the Korean case as a case that requires a heterodox explanation. 


\subsection{Neoliberal Hypothesis}

To examine the transition of an underdeveloped society based on agrarian activities and commodity extraction, we must first look at what was happening at the regional level in general. The World Bank (WB), in its 1993 report, highlighted that Asia's economic growth was developing together with an ongoing reduction in poverty, a situation it called "shared growth" (World Bank, 1993). According to Ozawa (2005), the population living on one dollar (extreme poverty) had decreased from $53.1 \%$ in 1984 to $26.5 \%$ in 2001 . This same thing occurred in Indonesia, where this population decreased from $37.8 \%$ in 1984 to $7.5 \%$ in 2002, and in Thailand, from 17.8\% in 1988 to 1.9\% in 2000. This author defends the idea that growth itself can reduce poverty, since each point of GDP growth implies a two-point reduction in Asian-Pacific poverty rate. Those who subscribe to these hypotheses defend the modern Flying Geese model, based on recycling comparative advantages from more modern countries to more backward countries (Booth, 1998). The World Bank report includes 9 causes that would explain shared growth in Asia:

1. Market-friendly, carefully limited government activities.

2. Strong export orientation.

3. High levels of domestic savings.

4. Human capital accumulation (universal education, skills training inside and outside firms).

5. Prudent macroeconomic management.

6. Effective and efficient acquisition of foreign technology.

7. Flexible labor market.

8. Agrarian reform and promotion of productive agrarian sectors.

9. Low inequality with high growth.

The World Bank guidelines are similar to what Stiglitz came to define as "market fundamentalists": an ideological approach that can only see benefits in the market and its actions, not considering any important role of the State in economic management (Stiglitz, 2003). This regional overview shows us that Korean development did not occur in isolation, but was a regional level process. It is therefore difficult to state that South Korea's development was a sui generi case, but for this same reason we must understand how South Korea rose to become a globalized, advanced, and developed economy. If these arguments were entirely true, in other words, that economic growth and poverty reductions occur simultaneously thanks to the fact that market forces can act freely, there would be no explanation for the 1997 crisis. For this very reason, Paul Krugman (1994) asks if we can really talk about an Asian miracle. The author distinguishes between TFP and capital investment. During the period between the end of the Korean War and the second oil crisis (1953-1980) growth can be explained by TFP, while after that period growth was due more to increased capital investments via FDI. Increased FDI for promoting TFP growth led to a dependence on foreign capital investment, making it difficult for capital to be removed in situations of embezzlement. The crisis was, therefore, a chronicle of a death foretold. Krugman's arguments are supported by Jeong (1991), who maintains that productivity grew 1.7\% between 1966 and 1990, while GDP grew 6\% in the same period. Thus, according to the author, growth would be a product of TFP.

\subsection{Environmental hypothesis}

The arguments of those who believe initial conditions are vital focus on factors such as geography (absence or not of natural resources), demography (age structure, population density, life expectancy), high levels of internal savings, or initial education levels as important to explain accelerated growth (García-Blanch, 2001). For these same reasons, there are those who consider that initial conditions are determinant but unexplainable, nonetheless. Under 
this premise, Kim (1991) states that Confucianism, aid from United States and Japan, social homogeneity without class structure, a good initial education system, an absence of repeated coups d'état, wage stagnation, no social welfare system, high international demand between 1953 and 1990, and the Vietnam War are all factors that influenced South Korea's accelerated growth and cannot therefore be extrapolated to other cases.

\subsection{Institutional Hypothesis}

Authors that assign relevance to the role of institutions find that their appearance was essential to explain Korean growth. The legacy of the government of Rhee Syngman, South Korea's first elected president, was the creation of a civil (1953), criminal (1954) and property rights code (1957) soon after the war ended. A code of commerce (1962) and trade arbitration act (1966) would be drafted later. Other regulations were issued later, including a restriction on collective bargaining (1971), which was later reversed by a law on minimum wage, collective bargaining, and labor rights (1987). A law regulating monopolies and fair-trade was only passed in 1980. The existence of these laws at an early date became a deciding factor for the Korean miracle. For Rodrick (in García-Blanch, ob. cit.) the 5 institutions that guarantee growth are property rights institutions, regulatory institutions, institutions for macroeconomic stability, institutions for social security, and institutions for conflict resolution. Along with bureaucratic quality and corruption controls, institutional performance is a sufficient condition for Korean development.

\subsection{Heterodox Hypothesis}

The concern of those who consider that both the market and the State are simultaneously responsible for development centers on which specific factor affects growth. García-Blanch (ob. cit.) states, counter to the statements in this article, that neither human capital nor TFP have increased sufficiently so as to be able to explain South Korean growth by themselves. For the author, capital accumulation is important when accompanied by increased productivity, while human capital growth is moderate. The foundations for Korean growth should not be explained using neoclassical premises, he points out, and says that these foundations are rather devaluation, political stability, the absence of war, an increased presence of the State in the economy, and an almost entire absence of civilian rights and freedoms. The author concludes, using a multifactor regression analysis, that processes of capital accumulation are explained by export promotion, local industry development, and changes made by the State to its management throughout 1961-1991.

Along these same lines, while making a comparison between Latin America and Southeast Asia, Weiss (2003) puts forward three ideas: that the demand structure has no implications for efficiency; that the role of demand only partially reveals market size and each country's GDP; and Latin America is not catching up to East and Southeast Asia due to problems with job allocation efficiency, per-worker productivity, and wages. Increased efficiency has improved together with liberalization since 1980, while, in Latin America, growth has always been linked to manufacturing, which negatively impacted employment in the latter and strengthened the services sector. This is because the business structure of Latin America is considerably different from that of East and Southeast Asia: R\&D investment is five times less; research license fees are five times less; and the value of exports is three times less. 


\subsubsection{The Flying Geese Model ${ }^{2}$}

A second hypothesis states that the lift-off towards development in South Korea was a product of what is known as the "Flying Geese" model, a development model that combines regional integration, international division of labor, and the role of a hegemon in the catching up process. The Flying Geese (FG) model is based on the elements provided by Kamane Akamatsu, a Japanese theorist who used a model based on the Hegelian dialectic applied to production (Kasahara, 2013). For Akamatsu, each country and each sector of the economy has 3 curves: an import, a production, and an export curve. These curves model the competitiveness levels of each sector/country. Competitiveness begins with local production, which gradually replaces imports, to then create surpluses that end up as exports. This process can then be transferred to goods, which start as basic goods and evolve into refined and complex consumer goods. For Akamatsu, this model has 4 phases:

1. Imports of consumer goods and exports of primary goods.

2. Imports of capital goods, exports of primary consumer goods.

3. Exports of consumer goods, some capital goods and imports of raw materials and some capital goods.

4. Decline of exports of consumer goods to capital goods and imports of what is not produced locally.

The transition from the first to the second phase occurs due to an abundance of raw materials that allow the attainment of export surpluses; the transition from the third to the fourth phase occurs due to a combination of Import Substitution Industrialization combined with export promotion. In the last phase, the local economy now competes with developed countries on the world market. This process is represented as follows:

\section{Graphic 1: FG model in two phases}

Panel A

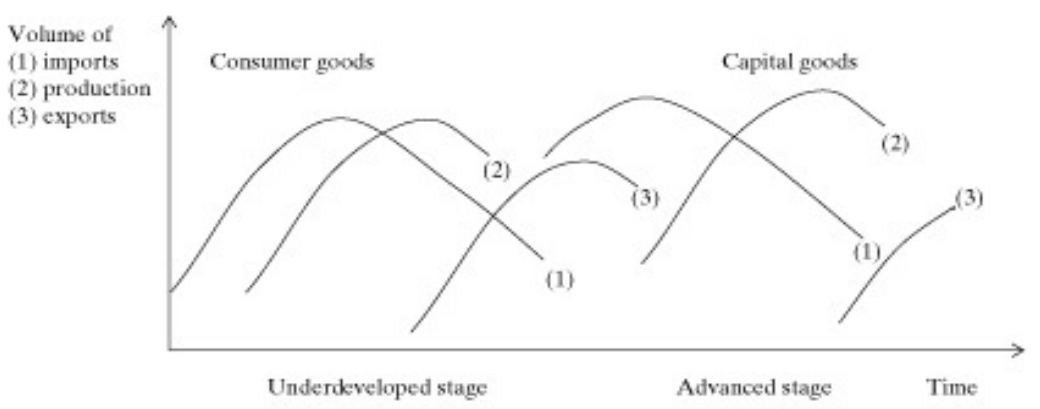

Panel B

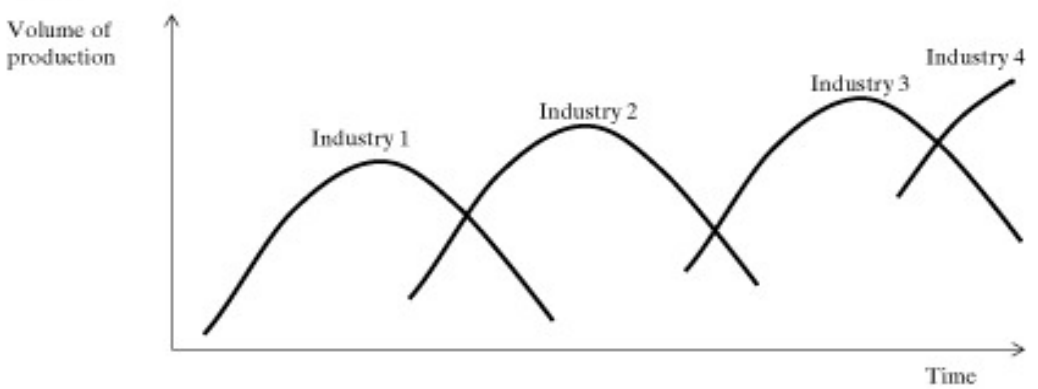

Source: Kiyota, 2015

2 As this model is more complex than other approaches, we will consider it separately from other heterodox approaches. 
As seen in the graph (Panel A), an internal industrial evolution generates a specific type of demand that must be satisfied by specific imports (1). As industrialization progresses, so do production volumes (2). As production increases, so do exports. Sustaining this process over time, the transition from a simple industry to a complex one allows moving production from consumer goods to capital goods, and then on to complex goods.

FG materialization can arise from two approaches: market state versus developmental state. In the first case there is what Vernon (in World Bank, ob. cit.) called the product cycle, under which the production of goods in a market, when their production has moved from an early phase to a more mature one, is disrupted from a developing country to a developed one. FDI replaces the export process. Kumagai (in Kasahara, ob. cit.) calls this process "reverse import". The modern FG model focuses on transformations of economies in regional contexts and sees companies as benevolent transmitters of industrial knowledge via FDI. Finally, the modern FG model states that economies must realistically choose which sectors to promote for industrialization, based on their ability to recycle comparative advantages from others instead of competing with the most advanced countries.

Although FG explains much of the GDP growth in South Korea (and in most countries in the Asia Pacific region), it lacks treatment concerning the composition of Capital accumulation. Is not the same to say accelerated growth comes from PC (which is the standard thesis) as it is to provide an explanation on how Capital is composed of more features, including $\mathrm{HC}$ development. As we will see in our model, TFP development is correlated with $\mathrm{HC}$ accumulation, which provides a more concrete explanation for South Korea's accelerated growth.

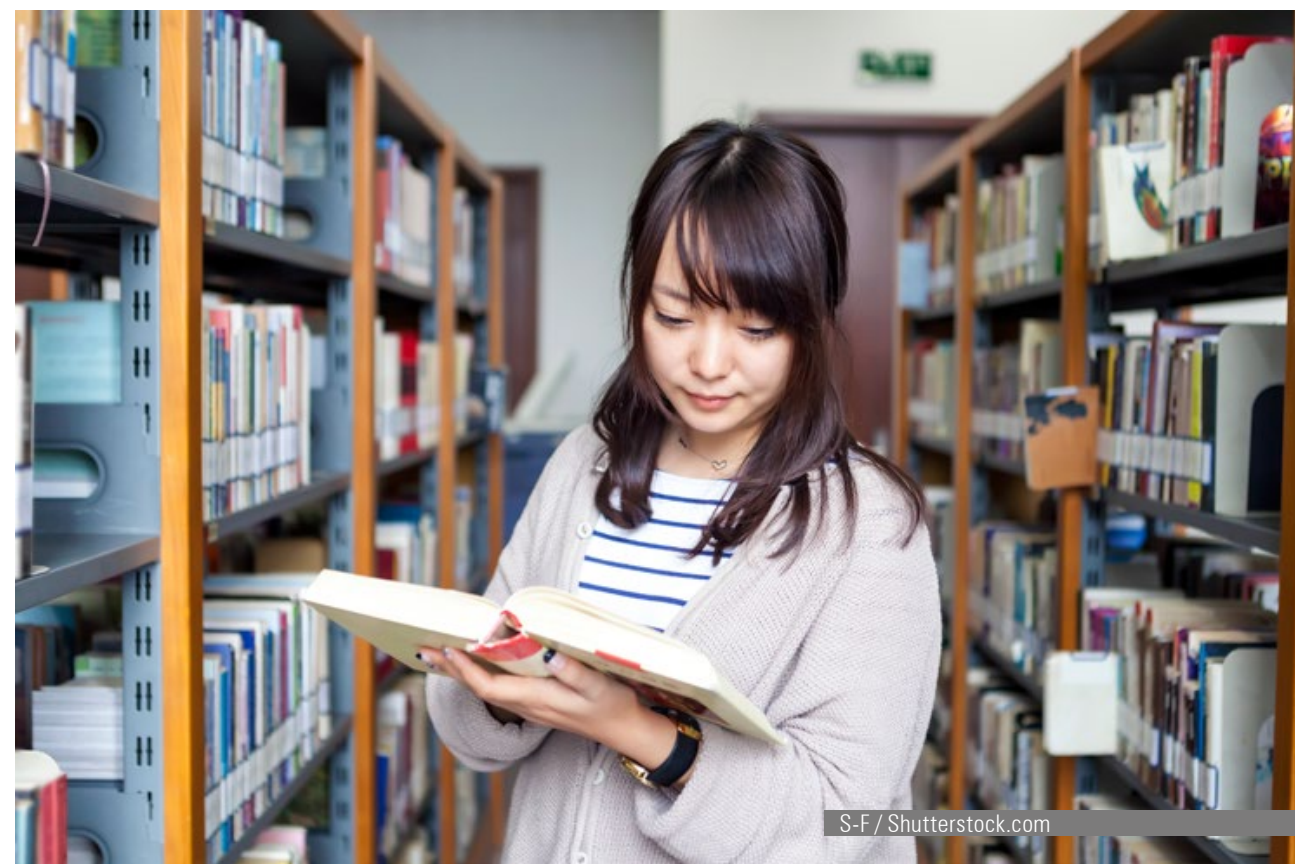

\section{THE 1960-1979 PERIOD: LIFT-OFF TO DEVELOPMENT}

South Korea's GDP in 1960 was equivalent to that of Sudan and the Republic of Congo (Heng, 2010). For an even more graphic comparison, prior to 1963 , South Korea's GDP was lower than that of Bolivia and Mozambique 
(Noland, 2011). By 1960, South Korea's real GDP per worker was only 584 dollars. In this section we will discuss how the literature has told the story of South Korea's economic growth, and how the FG approach is the most agreed-upon hypothesis for South Korea's lift-off to development. However, these hypotheses say little about how education and knowledge improved South Korea's Output per worker.

Contemporary Korean history places it as historically subordinate to Japan. As Noland (ob. cit.) rightly points out, Korea was annexed by this country in 1910 and its future independence was agreed at the 1943 Cairo Conference, a resolution that was later echoed at the 1945 Potsdam Conference. The consequences of World War II were disastrous for both Japan and Korea: industrial and agricultural production was below post-war levels, their PC was almost useless, and they had almost 3-digit inflation. In the case of Japan, the Supreme Commander of the allied troops had restricted coal and oil imports, both vital to an economy without natural resources like the Japanese one. The rebuilding of Japan became a strategic factor when the Korean War broke out in 1953, making it a priority for the United States to invest in lifting up its economy and prevent the spread of communism in Southeast Asia (Heng, ob. cit.).

South Korea inherited an economically interventionist system of government from the Japanese occupation period during the Yi dynasty. 94 percent of Korean industrial property was in Japanese hands. However, after 1947 these properties began to be sold under pressure from the United States and then due to Rhee's rise to power. The Chaebol, a traditional Korean form of organization, was inherited from the Japanese Keiretsu. The Keiretsu were groups of companies with intense trade between them. At their center, a bank was established with extensive powers (Heng, ob. cit.). Due to the development of the Keiretsu, Japan doubled its capacity for economic growth every 7 years between 1950-73. The Korean chaebo/s, in turn, enabled using the all the workforce left unused by after the Japanese occupation and the subsequent war between the two Koreas.

When Park Chung-Hee came to power in 1961 via a coup d'état, he created the conditions that allowed the development of the " 3 lows": low grain price, low exchange rate, and low interest rate. This authoritarian government oversaw a distributive income policy and broad participation of the industrial sector in the economy. Between 1954-86, the share of industry in the GDP went from $12.2 \%$ to $30.2 \%$ and the agricultural sector saw its share decrease from $44.6 \%$ to $13.5 \%$ (Kim, 1991). Savings went from a negative rate $(-3.8 \%)$ to $23.1 \%$ in 1973 (Frank and Kim, ob. cit.). The Korean development strategy was based on 3 stages:

1. Import Substitution Industrialization (ISI): The infrastructure for industrial development was built between 1954 and 1960.

2. Export Oriented Industrialization (EOI): between 1961 and 1979 an export-oriented industrialization phase took place. This phase was implemented by General Park in conjunction with his development plan.

3. Restructuring: Implemented after the debt crisis in 1980 to end stagflation. This period began the liberalization of the economy seeking to eliminate rigidities inherited from the Park period.

These periods, as divided above, match the five-year plans developed by General Park to organize the economy. The first five-year plan was implemented in 1962, and they governed Korean economic activity until the 1997 crisis. The goals of the first five-year plan were to grow energy reserves, increase agricultural production, expand the size and relevance of key industries for the period, improve the balance of payments, promote technological development, and conserve national lands. In turn, the second five-year plan prioritized food self-sufficiency, industrialization based on chemical, steel, iron, and heavy industries, an improved balance of payments (achieving USD 700 
million in exports and USD 500 million in exports of commodities) to reach 1971 with an ISI model, limited population growth, increased agricultural productivity, and the promotion of scientific activity and management skills (Frank and Kim, ob. cit.).

Highlighting the role played by the above two five-year plans is relevant because they laid the foundations for the Korean accumulation process that would allow its economy to lift off. The first plan used a dual strategy that promoted commodity exports while using their surpluses for industrial development. The second plan, having already built basic industrial infrastructure, implemented a strategy for developing a heavy industry of its own to achieve the self-sufficiency required to maintain GDP high through the development of its internal market using an ISI strategy. It should be noted that both plans were achieved in such a way that the money supply increased dramatically, explaining why long-term projects were financed almost entirely by the State. However, the cash surplus would lead to high levels of inflation. To correct the issues with inflation and low growth registered in 1972, the Presidential Emergency Decree for Economic Stability and Growth was issued. Its objectives were to transform the poorly organized money markets into long-term markets at low interest rates (in exchange for freezing their funds for 6 months to 3 years) by $1.35 \%$, lowering the general interest rate from $19 \%$ to $15.5 \%$ and from $16.8 \%$ to $12 \%$ for one-year term deposits, the authorization of a special depreciation in capital value for specific industries from $40 \%$ to $80 \%$, and a stable exchange rate of 400 won to USD. Under this plan, the balance of payments improved, improving South Korea's competitiveness and stabilizing local production.

For Acemoglu, Aghion and Zilibotti (in Voegeli, s / a) development is a dynamic process under which nations accumulate technology by imitation or innovation. Once a country reaches a standard similar to that of developed nations, innovation becomes critical to maintain TFP at optimal performance. The speed at which a country grows, states Voegeli (ob. cit.), depends on its institutions. In underdeveloped countries, growth can be achieved by imitating the technology of developed countries. At an institutional level, States can implement two types of policies, namely rigid (market protection, barriers to entry, selective support for companies, employment protection and direct government influence) or flexible (long-term contracts, innovation-based investment strategies). The basis for the Korean model was the use of rigid policies to achieve a process of technological accumulation through imitation and the use of reverse engineering. This model was easily maintained because Western countries did not patent the technology they used to design their products. After the oil crisis, developed countries became more reluctant to share their knowledge so freely. Korean companies started as parts assemblers and then transformed into large companies with their own production, such as Hyundai, Kia, or Daewoo. After 1975, these companies made the leap to local production.

During Park's dictatorship, the government covered investment risks by providing high sums of venture capital. Development of the automotive sector was promoted during the 1970s by increasing the cost of importing cars but allowing the parts to enter for artisanal assembly. Already by the end of the 1970s, a third of the capital goods produced in South Korea were for export. Automotive development allowed expanding this form of production to the production of televisions, microwaves, video tapes, stereo equipment, and digital clocks (Kim, 1991). For implementing this type of activity, the government prioritized large companies over Small \& Medium Enterprises. It was assumed that international demand was what determined the production of goods and productivity and, therefore, the South Korea's international competitiveness. To maintain this virtuous cycle, the government combined state and trade policy towards converging objectives. The State and state-owned companies made $40 \%$ of the investments in infrastructure in 1963-80. Be- 
tween 1977 and 1980, 76\% of public investment went to infrastructure. The state companies thus fulfilled a double function of creating a base infrastructure and serving as a generator of inputs to the global value chain. However, the effects of these policies created strong inflationary pressures on the budget. To correct these problems, the government introduced a set of reforms that helped control inflation until the crisis of 1980.

Under Park's plan, the chaebols would play a fundamental role in the development of the economy, as the axis of Korean industrialization. Their emergence and growth are explained as a product of state policies, which enabled multi-sector development of the chaebols through soft loans. However, their growth was fostered at the expense of SMEs, so the other side of the Korean model's currency was economic concentration. The government supported the chaebo/s so they could compete against foreign supply, which created a dual market for large companies with high market powers and SMEs with no impact on the international market (Kim, ob. cit.; Ozawa, ob. cit.; Noland, ob. cit.). Large companies became dependent on international funds, which accounted for $85 \%$ of their financing in 1980. Until 1978, SMEs accounted for $95 \%$ of all companies, $50 \%$ percent of the labor force and a third of Korean production.

The chaebols were agglomerations of companies led by a family or clan that were founders and investors. They were similar to clusters and originated from monopoly or oligopoly conditions created by the Korean government. According to data from Harvie (2006) for 1997, 93 percent of commodities and $62 \%$ of shipments were made under monopoly or oligopoly conditions. Thanks to their size, vertical integration, and diversification, an appropriate imitative capacity was enabled for large investment projects in imitative activities. The chaebols began by imitating and then moved on to innovating, since through imitation they assimilated the foreign technology necessary to develop local production. The chaebols gave their workers the freedom to build careers and to change companies, an area where they are different from the Japanese keiretsu where people made a career for life in a single company.

The chaebol had its own non-bank financing agencies and help from the government and the banks when they required financing (which was in most cases). All decisions went to the General Manager, who was generally the clan or family head. However, unlimited financing caused 15 of the top 30 chaebols to fail during the crisis of 1997. Monopolistic or oligopolistic conditions are reflected in a declining number of SMEs and it corresponding impact on production and work. SMEs did not receive preferential financing, and the only way they could survive was as part of a chaebols' chain of production, acting as subcontractors or suppliers of inputs. Chaebo/s acted subject to goals defined by the government, although they were free to decide how to achieve them. They had government help with financing and the control of external competition, creating a favorable environment for bridging the technology gap.

On a sectoral level, the electrical industry began development with the creation of the chaebo/ Lucky Goldstar (LG), a company that got its start assembling amplitude modulation radios. Its growth and development occurred due to reverse engineering, which allowed them to develop their own production and then export it. Due to restricted patents for color TVs, LG decided to move towards local research in cooperation with universities and international projects. In 1975, Samsung became the first company to deliver to the semiconductor business, and by 1983 Daewoo, LG and Samsung were integrated for jointly developing very large-scale projects. By 1987, these companies had managed to bridge the technology gap with Japan to one year in the semiconductor industry and, by 1994, they had closed it completely. It should be noted that PC growth was exponential and $\mathrm{HC}$ growth was linear for the 1953-90 period. Accumulated capital stock in 1990 was 31.2 times higher than in 1961 (García- Blanch, ob. cit.). 
As can be seen in section one and two, several explanations exist for Korea's lift-off. The FG model is most widely accepted due to its multi-level analysis of GDP growth: Countries create a hierarchical structure where most technologically developed countries recycle their comparative advantages to less developed countries. The historical evidence in section two confirms the FG model: Korea benefitted from this recycling process by combining an Exports Oriented Industrialization, the active role of the State and the use of the international market to accomplish the different, subsequent five-year plans. The state was a central actor for the creation of a unit responsible for production: the chaebol. The FG model explains a growth in output driven by forces boosting demand for low value and capital-intensive goods. However, the FG model would not be capable of supporting this demand of goods if TFP did not have an important synergy with $\mathrm{HC}$. The next section will explain how $\mathrm{HC}$ and Knowledge impacts Output.

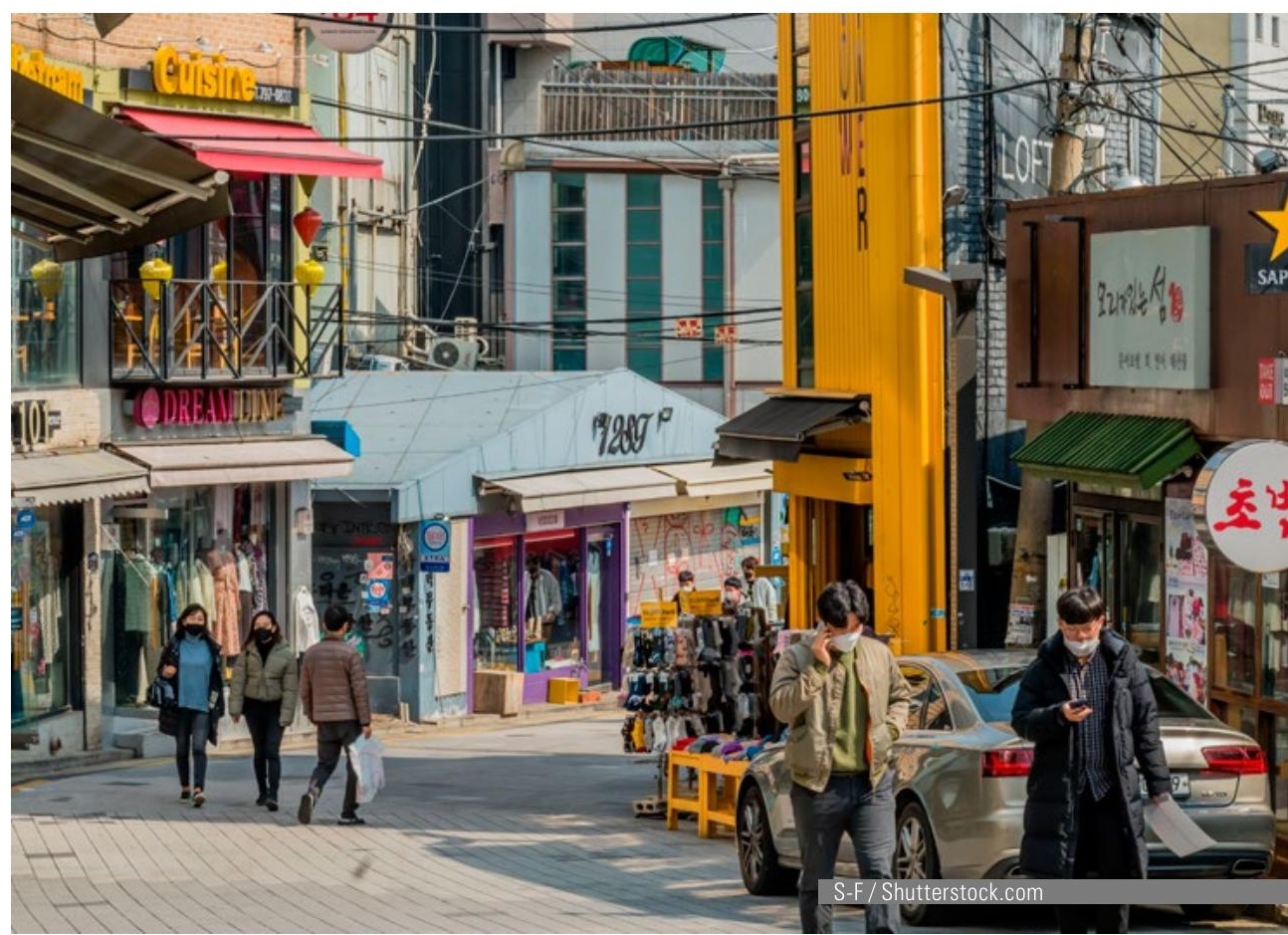

\section{SOUTH KOREA'S LIFT-OFF: A DEMI- EXOGENOUS HUMAN AND PHYSICAL CAPITAL MODEL}

The goal of this section is to formulate a model that combines the benefits of an exogenous growth approach without developing a bias concerning technological development (Knowledge) as given. We propose to study the Korean case using the Solow model of exogenous technological development. This model allows seeing how Korea moved towards a Balance Growth Path based on the behavior of Capital and effective Labor ( $K$ and $A L$, respectively). We redefine the model with $\mathrm{HC}$ and $\mathrm{PC}$ as variables within the model. Finally, we assume that the growth rates of Labor, Technological development, and Capital as constant. 


\subsection{Description and assumptions of the solow model}

The Solow Model is one of the most expanded and used models to explain the impact of Capital, Effective Labor and Technology on Output. The Solow model explains growth from a macroeconomic perspective concerning the role of productive factors in firms used for Output. The model is defined using a Cobb-Douglas Production Function (CDPF), where capital shows diminishing returns of scale.

The model uses 4 variables: Output $(Y)$, Capital $(K)$, Labor $(L)$ and Knowledge $(A)$. The production function takes the form,

$$
Y(t)=F(K(t), A(t), L(t))
$$

To simplify the model, $A$ and $L$ enter multiplicatively as $A L$ as effective labor (Romer, 2012). This ensures in a certain point the ratio $Y / K$ will settle down. The production function, as said earlier, uses a CDPF and constant returns of scale. Constant returns of scale assumption are displayed as,

$$
\begin{gathered}
F(c K, c A L)=c F(K, A L) \quad \text { for all } c \geq 0 \\
F\left(\frac{K}{A L}, 1\right)=\frac{1}{A L} F(K, A L)
\end{gathered}
$$

We define $k=K / A L, y=Y / A L$ and $f(k)=F(k, 1)$. Thus, we can redefine $y$ as,

$$
y=f(k)
$$

In other words, we display Output per unit of effective labor ${ }^{3}$ as a function of Capital per Unit of Effective Labor (UEL from now on). Because our production function is a CDPF with constant returns of scale we can get the intensive form of the production function. When multiplying both inputs by the constant value $\boldsymbol{C}$ we get,

$$
\begin{aligned}
F(c K, c A L) & =(c K)^{\alpha}(c A L)^{1-\alpha} \\
& =c^{\alpha} c^{1-\alpha} K^{\alpha}(A L)^{1-\alpha} \\
& =c F(K, A L)
\end{aligned}
$$

We then divide both inputs by $A L$, obtaining,

$$
\begin{aligned}
f(k) & \equiv F\left(\frac{K}{A L}, 1\right) \\
& =\left(\frac{K}{A L}\right)^{\alpha} \\
& =k^{\alpha}
\end{aligned}
$$

With this intensive form the first partial derivative of the production function takes the form,

$$
f^{\prime}(k)=\propto k^{\propto-1}
$$

\footnotetext{
3 We define effective labor as the product of 1 unit of Labor and 1 unit of knowledge, A times L. Labor combined with knowledge reflects real Labor or "effective labor". This unit will be used only for the convergence section of the model.
} 
As the initial levels for $K, L$ and $A$ are taken as given and we assume they grow at a constant rate, we define their growth rate as a derivative of time,

$$
\begin{aligned}
& \dot{L}(t)=n L(t) \\
& \dot{A}(t)=g A(t)
\end{aligned}
$$

Output is divided between consumption and investment. The fraction assigned to investment is exogeneous and constant and named. Capital depreciates at a rate of $\delta$,

$$
\dot{K}(t)=s Y(t)-\delta K(t)
$$

\subsection{The balanced growth path in the solow model}

Model dynamics aim to establish all economic trends to set in a balanced growth path where diminishing returns on capital explain a stationary state where output per worker does not increase at increasing levels of capital. The model predicts a convergence where the first partial derivative of capital per unit of effective labor is zero.

We now focus on capital dynamics per UEL, $k$. Knowing that $k$ equals $K /$ $A L$, we apply the chain rule to the production function to obtain,

$$
\begin{aligned}
\dot{k}(t) & =\frac{\dot{K}}{A(t) L(t)}-\frac{K(t)}{[A(t) L(t)]^{2}}[A(t) \dot{L}(t)+L(t) \dot{A}(t)] \\
& =\frac{\dot{K}}{A(t) L(t)}-\frac{K(t)}{A(t) L(t)} \frac{\dot{L}(t)}{L(t)}-\frac{K(t)}{A(t) L(t)} \frac{\dot{A}(t)}{A(t)}
\end{aligned}
$$

As we defined $\dot{L}(t)=n L(t)$ and $\dot{A}(t)=g A(t)$ as the growth rates of $L$ and $A$, we can replace these values with their values in the chain rule equation. Plus, $\dot{K}$ is the difference between the saving rate and depreciation. We can thus rewrite the equation as,

$$
\begin{gathered}
\dot{k}(t)=\frac{s Y(t)-\delta K(t)}{A(t) L(t)}-k(t) n-k(t) g \\
\quad=s \frac{Y(t)}{A(t) L(t)}-\delta k(t)-n k(t)-g k(t) \\
\text { Because } f(k)=Y / A L \text { we obtain, } \\
\dot{k}(t)=s f(k(t))-(n+g+\delta) k(t)
\end{gathered}
$$

This equation is the key equation in the Solow model, where equilibrium for capital accumulation is $k^{*}=\dot{k}$. It defines that the rate change in capital stock is produced by the difference between actual investment and break-even investment. The first, defined by $s f(k(t))$, is the amount of capital per UEL multiplied by the fraction invested in savings. The second term, $(n+g+\delta) k(t)$ , is the value needed to keep the level of at its actual level defined as the Balanced Growth Path4 (BGP) of the economy.

4 The Balanced Growth Path is the point at which the factors that depreciate $K$ are equal to the savings rate. At this point the economy arrives at a stationary state, where Output per worker is maximum, and $k$ and $y$ growth rates are equal to $(n+g)$. 
It is important to note that, as mentioned before, a diminishing return of scale ensures the model converges to a point where $\dot{k}(t)$ equals zero. As the value of $k$ increases, it will converge to a point where equals zero. This means all the variables increase at a constant rate. The model also establishes that only technological changes can create growth effects. All other elements (investment, consumption, capital, labor, savings) will have a leveling effect.

To ensure the existence of a point where $\dot{k}(t)$ equals zero we need to establish how the Solow model reaches equilibrium. Our initial equation takes the value of $\dot{k}(t)=0$ and $k^{*}=k$ which represents the economy's BGP,

$$
\begin{gathered}
0=s f(k(t))-(n+g+\delta) k(t) \\
s k^{\alpha}=(n+g+\delta) k \\
k^{* \alpha}=\left(\frac{n+g+\delta}{s}\right) k^{*} \\
k^{*}=\left(\frac{n+g+\delta}{s}\right)^{1-\propto}
\end{gathered}
$$

By transforming this expression, we obtain optimum capital in the BGP as a proportion of the savings rate,

$$
k^{*}=\left(\frac{s}{n+g+\delta}\right)^{\frac{1}{1-\alpha}}
$$

To obtain the optimum output level we replace the value of $k$ with $y=f(k)$

$$
y^{*}=\left(\frac{s}{n+g+\delta}\right)^{\frac{\alpha}{1-\alpha}}
$$

The results of the Solow model show that, to achieve a maximum level of consumption per UEL we require certain levels of investment or, otherwise, maximum growth cannot be achieved at certain levels of the exogenous saving rate. We continue to modify the Solow model to ensure a comprehensive explanation of Capital Composition.

\subsection{Modified Solow model including human capital}

As the Solow model does not define changes in or the behavior of knowledge A, we need to solve how A contributes to Output. One way to determine the contribution of technology to growth is to calculate $A$ as a residual. This residual determines Output for a given amount of $\mathrm{PC}$ and Labor services. First, we define CDPF as a combination of PC and effective labor services,

$$
Y=K^{\alpha}(A H)^{1-\alpha}
$$

We divide CDPF by the number of workers $L$ and, using logs, we get,

$$
\ln \frac{Y}{L}=\alpha \ln \frac{K}{L}+(1-\alpha) \ln \frac{H}{L}+(1-\alpha) \ln A
$$

This equation expresses the effects on Output per worker growth rates as a function of the growth rates of Capital and HC per worker and Knowledge 
$\ln A$. It will be equal to all the factors not concerning $L$ or $\mathrm{K}$. The value $\ln A$ is defined as TFP. If we take TFP and subtract $\alpha \ln \frac{Y}{L}$ we obtain,

$$
(1-\alpha) \ln \frac{Y}{L}=\left(\alpha \ln \frac{K}{L}-\alpha \ln \frac{Y}{L}\right)+(1-\alpha) \ln \frac{H}{L}+(1-\alpha) \ln A
$$

Dividng both sides by $1-\alpha$ we obtain,

$$
\ln \frac{Y}{L}=\frac{\alpha}{(1-\alpha)} \ln \frac{K}{Y}+\ln \frac{H}{L}+\ln A
$$

As a result, the new equation expresses Output per worker as the combination of Capital elasticity per worker, $\mathrm{HC}$ per worker and Knowledge log A. The new function expresses the growth rates of human services and TFP as independent of the capital growth rate. This will be the base equation for our Multivariable Regression Model (MRM) analysis using the modified Solow model.

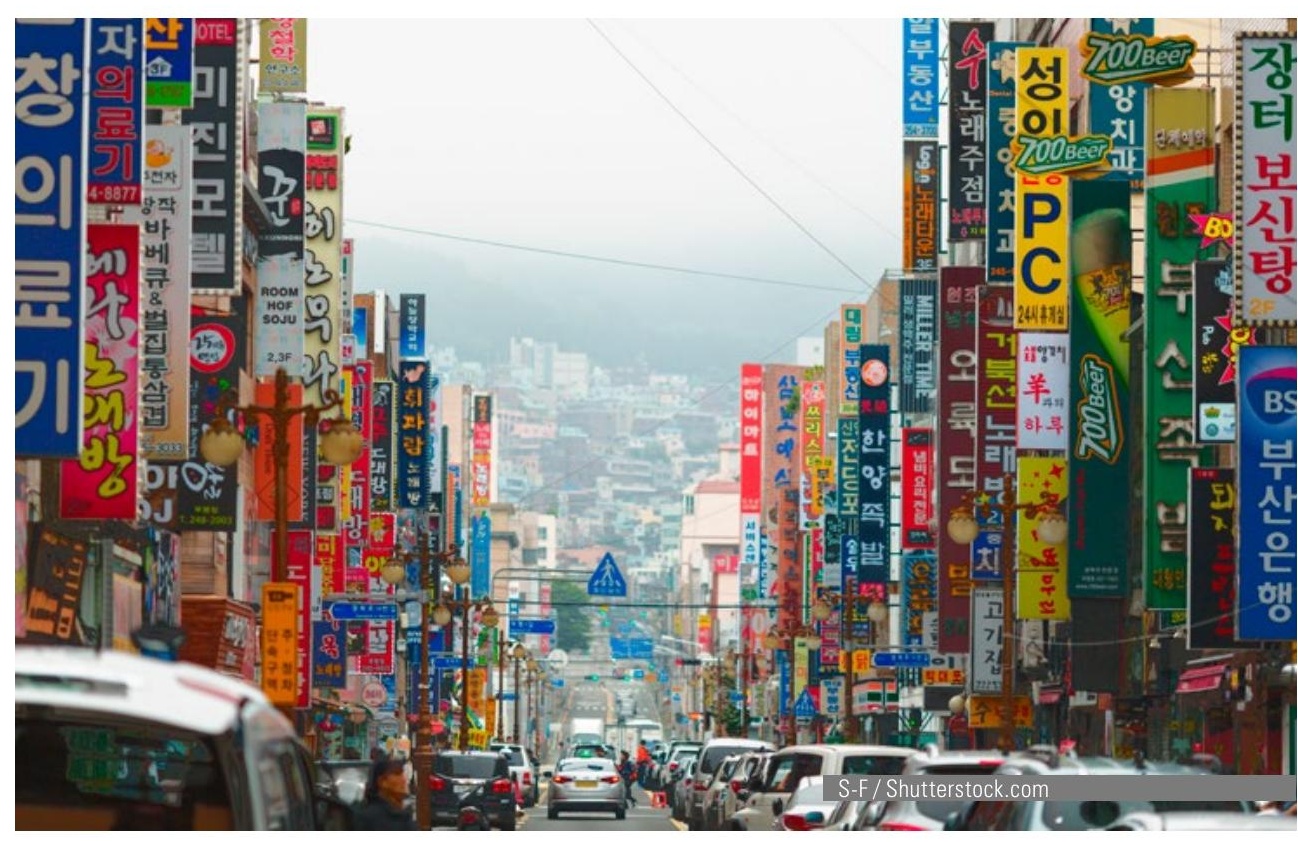

\subsection{The econometric model of the modified solow model}

In the following section we will develop a modified Solow model. Our explanatory variables are Output per worker, Physical Capital per Output $(K / Y)$, Human Capital per worker $(H / L)$ (and Total Factor Productivity $(A)$. We use the World Bank Dataset and Penn World Table 10 to create our variables. We run an MRM for the sample between 1960 and 1979. Finally, we use a slope equal to zero (no impact on Output per worker) as a null hypothesis estimator for all independent variables.

The model uses the variables $Y, K, L$ and $\boldsymbol{A}$ like the classical Solow model: Output, Capital, Labor, and Knowledge. Output is measured as the real GDP index; Capital is measured using the Gross Capital Formation index; Labor uses the total number of workers per year; Knowledge takes the form of Total Factor Productivity, calculated using the relative income method con- 
cerning optimum capital performance ${ }^{5}$.

We incorporate $\mathrm{HC}$ as variable, dividing capital in two types: Physical and Human. PC is Gross Capital Formation and increases at a rate of $1-\propto ; \mathrm{HC}$ incorporates years of school population and grows at a rate of ; Technology is equal to TFP, assumes the value of $A$ and grows at a rate of $g$; Labor is the number of workers and grows at a rate of $\boldsymbol{n}$; Depreciation is equal to capital devaluation and grows at a rate of $\boldsymbol{\delta}$; Finally, the share of output destined to savings grows at a rate of $S$. Estimators $n, g, s$ and $\delta$ are continuous and were calculated for the period 1960-1979 as is customary for the BGP.

\subsubsection{South Korea's Balanced Growth Path}

The BGP for 1960-1979 applies the Solow model applying, as a main assumption, a constant growth rate of Labor, Knowledge, and Depreciation. We have estimated constant values for Labor, Knowledge, Savings, and Depreciation rates. These values are calculated as averages for the period being studied to achieve constant growth rates for the model. Output $(Y)$, Capital $(\mathrm{K})$, Technology (A), and Labor (L) evolve over time. As our analysis assumes a closed economy, Output is the sum of total Consumption and Investments not including Imports and Exports. We assume total Output is destined for Consumption (C) and Savings (S). For simplification, Investments and Savings are assumed to be equal $(I=S)$. We need to observe more closely the data obtained to see how the Solow Model explains the South Korea case.

First, a typical relationship exists between the share of capital destined for investment $(s Y)$ and capital depreciation $(n+g+\delta) k$. As can be seen in the graph, first there is the need to accumulate capital as savings to later use this investment to increase growth. South Korea's economy starts out as a typical case where capital composition leads to an early stationary state. Consumption begins as is typical in underdeveloped countries where most of their income is destined to this item to progressively increase savings.

Graph 2: Actual Investment, BEI, and Optimum Capital for South Korea, 1960-1979

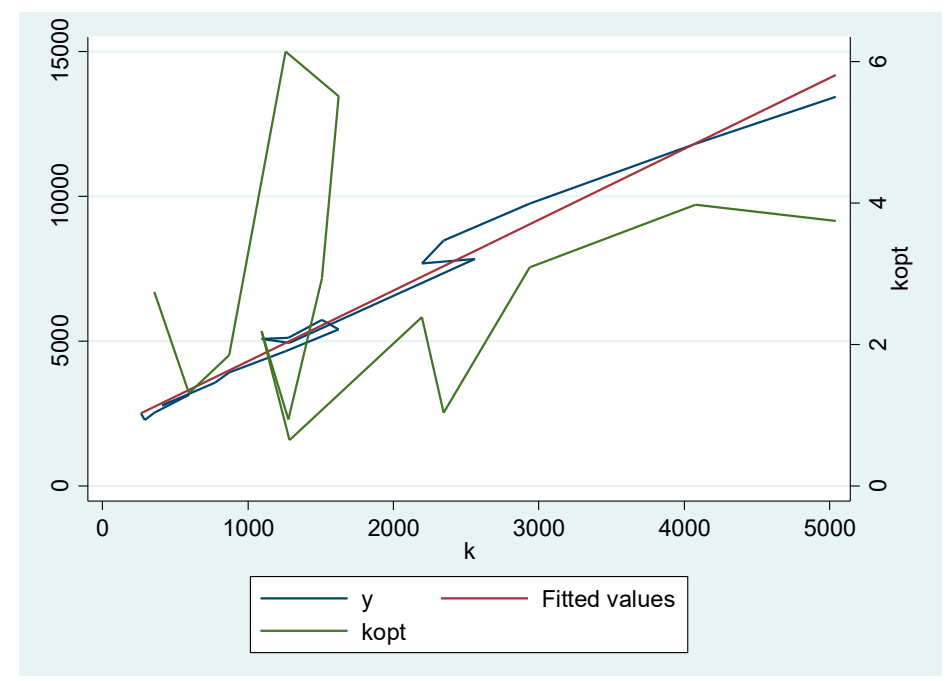

Source: Author using the World Bank Database

5 In the Solow model, TFP can be estimated by creating a quotient between income per worker (Y/L) in a given country and income per worker in the United States. As the Solow model states that the optimum share of capital to Output is $1 / 3$, we create a quotient between capital per worker at the optimum level $\left(\mathrm{k}^{1 / 3}\right)$ of any given country and the United States. Finally, we create a quotient between relative optimum capital and relative income per worker, which returns the value of $A$. 
The total Output per worker curve (blue curve) cuts across the BreakEven Investment (BEI) curve (red curve) accomplishing the foundation of the Solow Model. Despite the zig-zag like behavior of the first section of the total output curve, mostly explained by the higher levels of savings required for the Korean economy to achieve lift-off, the BGP is achieved. A stationary state is achieved early, explaining the important role played by investment in Korea's path for development. The form of both curves reveal South Korea underwent a difficult first stage of both saving and spending as industrialization became a national strategy for the country. Good initial saving rates benefit actual investment to maintain an upward trend throughout the period. The flat curve for Actual Investment reveals how important technological factors are for economic growth.

Over the analyzed period, the relationship between the saving rate (Gross Capital Formation) and the BEl (the sum of the increasing Labor, Knowledge and Depreciation rates) proves South Korea generated levels of capital over and above the depreciation factors in the Solow model but always converging to a stationary state with optimal capital per unit of effective labor converging to zero. As the graph below shows, the maximum values for the optimum capital $k^{*}$ are reached when the actual investment curve cuts across the BEl curve as the actual investment curve overtakes the BEI curve when the values for $k^{*}$ are minimum. This proves the Solow model is appliable to the South Korean case despite the fact that CGF levels are lower than optimum capital levels.

\subsubsection{Multifactorial linear regression}

As a first step we run an MRM using our modified Solow model isolating the effect of Capital on Output. We will set aside variable A to evaluate the impact of HC on Output per Worker as follows,

$$
\ln \frac{Y}{L}=.-.5238\left(\ln \frac{K}{Y}\right)+7.7940\left(\ln \frac{H}{Y}\right)
$$

$$
\begin{array}{lll}
(.4977956) & (1.135928) & R^{2}=.88
\end{array}
$$

The model evinces several problems with the regression results. First, results show that a regression without TFP omits variable bias as $\mathrm{HC}$ is overdetermined. Second, Elasticity for Capital on Output leads to an impact of Capital on Output that is inconsistent with historical data as Capital improves Output per worker and not vice versa. Third, robust Standard Deviation is considerably distorted, making the variable $\mathrm{K} / \mathrm{Y}$ not statistically significant for $t$-test and $p$-value hypothesis evaluation.

For these motives, we will include TFP in the MRM and evaluate the impact on Output per worker of Capital per Output, HC, and Knowledge as follows,

$$
\begin{aligned}
\ln \frac{Y}{L}= & .7348\left(\ln \frac{K}{Y}\right)+1.307\left(\ln \frac{H}{Y}\right)+1.5222(\ln A) \\
& (.0777071) \quad(.3574635) \quad(.0967378) \quad R^{2}=.99
\end{aligned}
$$

These results show the impact of Knowledge upon the growth rate of Output per worker and not as an error term. The t-statistic and p-values for the three variables allows rejecting the null hypothesis of a slope equal to zero. As .7348 is the elasticity of, we estimate an alpha value. These results present capital composition revealing a trade-off between Physical and Human Capital: the more human capital the more the growth rate of GDP per worker 
will increase. Knowledge proved to be an explanatory variable for changes in Output per capita growth rate, revealing a large and positive impact on the regression coefficient when TFP is combined with $\mathrm{HC}$. These results are consistent with the economic theory and historical evidence concerning the period being studied in South Korea, where doubts exist regarding whether TFP correlates more to Physical or Human Capital. The correlation test between $\mathrm{HC}$ and Knowledge is .75 meanwhile the correlation between PC and Knowledge is .52, suggesting that Knowledge increases quickly with $\mathrm{HC}$ rather than PC.

There are several explanations for this result. First, the ratio between $\mathrm{HC}$ and $\mathrm{PC}$ rates shows diminishing returns over the whole period. Second, South Korea underwent an economic crisis during the second half of the 1970s. The trade-off of capital composition shows PC was important, but it is $\mathrm{HC}$ that shows increasing rates for economic growth. This last factor is understandable since South Korea faced a transition from a heavy industry economy to a technology-based industry. Finally, the results are consistent with the notion that $\mathrm{HC}$ and Knowledge grows together, and PC loses its explanatory role for growth as more and more workers receive compulsory education.

\section{Conclusion}

This article seeks to answer the question of the role of human capital on growth during the first period of South Korea's development. Between 1960 and 1979 we see enormous results related to economic performance. In less than 20 years, South Korea managed to multiply by its GDP per worker by a factor of nearly six, double its TFP, and increase its savings rate almost 4 times, develop both a heavy and a technology-based industry, and almost double the number of workers with formal education.

In the first part we looked at the different theories that seek to provide an explanation for South Korea's performance. We argue that the main reason South Korea was able to achieve these results was as part of an international production system known as the Flying Geese model. However, to be included in the recylcing process of comparative advantages, basic infrastructure is required. Physical and Human Capital are fundamental for this process. For this reason, we needed to evaluate if $\mathrm{HC}$ played an important role in Capital accumulation alongside PC, which, according to the literature, was South Korea's main source of Output growth during its development. Modifying the Solow Model to evaluate the impact of Capital composition on growth has left some important conclusions.

First, at the beginning it was hard for South Korea to show good economic results because of the need to create savings conditions for industrial development. As the data shows, both savings rates and Gross Capital Formation increased during this period, enabling the creation of infrastructure for the chaebols and thus, fulfill the goals of the five-year plans. Second, South Korea reached BGP in the mid-term, showing that capital and labor are crucial components of economic growth. Human capital was crucial for South Korea, not for the industrialization process as such, but to enable a proper transition to next generation economic growth process based on highly skilled labor and technology. Finally, as stated by the literature, Knowledge proved to be fundamental to economic growth in this period as combined with human capital. This can be explained by a successful transition from one five-year plan to another until Knowledge became an engine for growth, which occurred mainly in the second half of the seventies and before the Asian crisis.

These results are consistent with the historical evidence but differ in the emphasis they give to PC. In the classical models, PC is the engine for growth. In the case of South Korea, HC and Knowledge played this role. This is not strange as capital accumulation is mainly explained by sources other than 
PC. This becomes clear as Korea mostly specialized in heavy industry but the transitioned to technology-intensive goods. This transition was made possible, as proven by this article, by the synergic impact of $\mathrm{HC}$ and Knowledge on Output per worker.

\section{Bibliography:}

- Banco Mundial. (1993). El milagro de Asia Oriental: el Crecimiento Económico y las Políticas Oficiales, recovered from http://documentos.bancomundial.org/curated/es/1993/09/15499989/east-asian-miracleeconomic-growth-public-policy-vol-2-2-resumen

- Berg, A. \& Krueger, A. (2002). Dar vela al comercio. Revista Finanzas y Desarrollo, pp. 16-19.

- Booth, A. (1998). Initial Conditions and Miraculous Growth: Why is South East Asia Different from Taiwan and South Korea? recovered from https://www.soas.ac.uk/economics/research/.../file28887.pdf.

- Feenstra, Robert C., Robert Inklaar and Marcel P. Timmer (2015), “The Next Generation of the Penn World Table" American Economic Review, 105(10), 3150-3182, available for download at www.ggdc.net/pwt

- Frank, C., Kim, Kwang Suk \& Westphal, L. (1975). Foreign Trade regimes and Economic Development. Cambridge: NBER Editions.

- García Blanch, F. (2001). An Empirical Inquiry into the Nature of South Korean Economic Growth. Center for International Development at Harvard University Working Papers, No. 74.

- Harvie, C. (2006). Sources of Economic Growth in South Korea: An Application of the ARDL Analysis in the Presence of Structural Breaks 1980-2005. V conference Korea and the World Economy, Korea University, Seoul, Korea.

- Heng Siam-Heng, M. (2010). The 2008 Financial Crisis and the Flying Geese Model. EAI Working Paper No. 156.

- Jeong, Jin-Young (1991). Large-scale company group and fair-trade system. Seoul: National Institute for Economic System and Information.

- Kasahara, S. (2013). The Asian Developmental State and the Flying Geese Paradigm. UNCTAD Discussion Papers.

- Kim, K. (1991). The Korean Miracle (1962-1989) Revisited: Myths and Realities in Strategy and Development. The Helen Kellog Institute for International Studies for International Studies, Discussion Paper \#166.

- Krugman, P. (1994). The Myth of Asia's Miracle. Foreign Affairs Review, Nov-Dec. No. 73, 6. ABI/INFORM Global, pp. 62-78.

- Noland, M. (2011). Korea's Growth Performance: Past and Future. East-West Center Working Papers No 1230zawa, T. (2005). Asia's Labor-Driven Economic Development, Flying-Geese Style: An Unprecedented Opportunity for the Poor to Rise? Discussion Paper No. 40. APEC Study Center, Columbia University.

- Romer, D. (2012). Advanced Macroeconomics. Fourth Edition. The McGraw Hill Series in Economics, New York.

- Sanguinetti, P. (2009). Comercio internacional y crecimiento económico en Chile. Periodo 1830-2000. Tesis para optar al grado de Magíster en Economía. Santiago: Universidad Católica de Chile.

- Stiglitz, J. (2003). El Rumbo de las Reformas. Hacia una Nueva Agenda para América Latina. Revista de la CEPAL N 80, pp.7-40.

- Voegeli, K. (No Year). Economic Growth through the Development Process: The Case of South Korea. Bachelor Thesis. Institute for Empirical Research in Economics, Switzerland: University of Zurich.

- Weiss, J. (2003). Industrialization in an age of globalization: some comparisons between East and Southeast Asia and Latin America, recovered from http: siteresources.worldbank.org/EXTEXPCOMNET/.../17_Weiss.pdf. 